\title{
Factors that Influence Vegetative Bud Development in Rootstock Segments of Dioscorea composita and D. floribunda ${ }^{1}$
}

\author{
Luis E. Gregory ${ }^{2}$ \\ INTRODUCTION
}

One of the most important sources of sapogenic precursors of cortisone and other steroid drugs is the tuberous rootstock ${ }^{3}$ of several Dioscorea species that grow wild in Mexico and Central America. Most of these steroidal precursors are extracted from the rootstocks of selections of Dioscorea composita Hemsl., D. floribunda Mort. and Gal., D. spiculiflora Hemsl. (Correll et al. (2)) ${ }^{4}$. Because several of the Dioscorea selections are unisexual and do not form seed, and because of the importance of working with high steroid-yielding clonal material in any commercial enterprise, it is important to have methods to propagate these plants asexually. One such method involves planting segments of the rootstock. However, a drawback to this method is the irregularity in time of sprouting of the segments. This uneven sprouting not only makes establishment of uniform plantations difficult, but, because of the high rot incidence of unsprouted pieces, it necessitates frequent replanting. Replanting involves high labor costs, as well as use of valuable tuberous rootstock from which the steroidal sapogenins are obtained. It would be of great economic value in the commercial cultivation of this crop if a way could be devised to induce the rootstock segments to readily initiate adventitious bud growth by releasing these segments from dormancy.

This paper discusses some inherent factors that affect the dormancy of the Dioscorea rootstock. In our experiments, dormancy involved the natural repression of bud formation in the rootstock tissues. Buds were produced when this dormancy was broken. A high-temperature treatment and a method of treating rootstock segments with a chemical that induced early and more uniform sprouting in strains of D. composita and D. floribunda are described.

${ }_{1}^{1}$ Research carried out at the Federal Experiment Station, Crops Research Division, Agricultural Research Service, U.S. Department of Agriculture, Mayagüez, P.R.

2 Plant Physiologist, Plant Hormone and Regulator Pioneering Research Laboratory, Crops Research Division, Agricultural Research Service, U.S. Department of Agriculture, Beltsville, Md.

${ }^{3}$ In this work the below-ground fleshy part of the Dioscorea plant will be referred to as a tuberous rootstock.

${ }^{4}$ Italic numbers in parentheses refer to Literature Cited, pp. 162-3. 


\section{MATERIALS AND METHODS}

GENERAL

Field-grown plants of D. floribunda (selections P.I. 199766, P.I. 200119, and Acc. 11566) and of D. composita (P.I. 201783) were used. P.I. 200119 is a clonal selection, the other three are sexual selections. The rootstocks were dug from the field and immediately washed to remove soil and debris. All fibrous roots were removed. The rootstocks were then cut transversely into segments. Those segments to be treated with ethylene chlorohydrin were placed in a 1 -gallon glass or a 5 -gallon plastic container. A dish containing a folded paper towel was placed on top of the segments, and a measured amount of the chemical poured on the towel. The container was covered with a metal or plastic lid and sealed with masking-tape. In the control treatments, the segments were placed in the sealed containers without the chemical added. After 8 hours, the segments were aerated. Treated and untreated segments were then dipped for about 3 to 5 minutes in a water slurry of Arasan ${ }^{5}$ fungicide, and planted horizontally with the ventral side down. In the greenhouse, the segments were planted in moist sphagnum or peat moss which was subsequently watered only when it had dried to a depth of about 1 inch from the surface. In the field, the segments were planted about 1 inch deep and watered when the soil around them had dried out.

The segments were examined at various time intervals for cracking and sprout formation on the dorsal side. Analysis of variance was used in the statistical treatment of the data.

\section{VARIATION IN SHOOT DEVELOPMENT}

To detect differences in shoot development among the Dioscorea selections, 3- to 4-inch segments of D. floribunda (P. I. 199766 and Acc. 11566) and D. composita (P.I. 201783) were planted directly in the field at 5-foot centers in rows 4 feet apart. The segments were covered with friable soil. Observations on sprouting were made 10, 15, 20, and 40 weeks after planting.

\section{DEVELOPMENT OF BUDS FROM DIFFERENT AREAS}

To study the variation in bud development from different areas of the rootstock, 3- to 4-inch tip and intermediate segments from six plants of D. composita (P.I. 210783) were obtained. In this paper, "crown" refers

5 Trade names are cited only for identification of materials used. Mention does not necessarily mean endorsement over similar products by the U.S. Department of Agriculture. 
to the area of the rootstock from which stems originated, "tip" to the area most distant from the crown, and "intermediate" to the area between the tip and the crown. Ethylene chlorohydrin was applied at the rates of 0.06 , 0.12 , and $0.25 \mathrm{ml}$. of chemical per liter, respectively, of container space to each of three groups of segments. Untreated segments served as controls. All segments were planted in sphagnum moss in the greenhouse. These were examined for bud formation 4,8 , and 12 weeks later.

\section{DEVELOPMENT OF BUDS AT DIFFERENT STAGES OF GROWTH}

Bud development in segments of rootstocks from plants in active growth' and from dormant plants, was studied in D. composita (P.I. 201783). The plants in active growth were harvested in the month of July and the dormant plants in December. The segments were treated and planted immediately after harvest. Ethylene chlorohydrin was applied at the rates of 0.06 and $0.12 \mathrm{ml}$. per liter, respectively, of container space to each of two groups of 3- to 4-inch intermediate segments. Untreated segments were the controls. All segments were planted in peat moss in the greenhouse and examined 4 and 8 weeks after planting.

\section{TEMPERATURE TREATMENTS}

For the temperature treatments, rootstocks of $D$. composita (P.I. 201783) and $D$. floribunda (P.I. 200119) were cut into 2- to 3-inch segments and divided into four groups. Each group was planted in moist sphagnum moss inside a cardboard box which was covered with plastic cloth to maintain the moisture. Three groups were placed in germinating ovens at $31^{\circ}, 35$, $^{\circ}$ and $43^{\circ} \mathrm{C}$., respectively. The fourth group was left to germinate at room temperature $\left(26^{\circ}\right.$ to $28^{\circ} \mathrm{C}$.). The segments were examined for bud formation 2,5 , and 9 weeks later.

\section{ETHYLENE CHLOROHYDRIN TREATMENTS}

To determine the effective concentrations of ethylene chlorohydrin to use for accelerating bud development, a test was carried out with both field and greenhouse plantings. Two groups of intermediate segments (70 to $80 \mathrm{~g}$. each) of $D$. composita (P.I. 201783) were treated with 0.06 and $0.12 \mathrm{ml}$., respectively, of the chemical per liter of container space. Untreated segments were the controls. Thirty segments were used per treatment and treatments were replicated five times. In the field the segments were covered with paper mulch; in the greenhouse they were planted in moist peat moss. Observations on sprouting were made 4,8 , and 12 weeks after planting. 


\section{RESULTS AND DISCUSSION}

\section{VARIATION IN RATE AND DEGREE OF BUD DEVELOPMENT AMONG DIOSCOREA SELECTIONS}

Marked variation in the rate and degree of bud development is often found among Dioscorea selections. This variation was observed in the sprouting of segments from two $D$. floribunda and one $D$. composita selections. Both the rate and degree of sprouting varied significantly between the two Dioscorea species and, to a lesser degree, between the two $D$. floribunda selections. In the $D$. floribunda selections there was a high percentage of sprouting at the first examination period, while very low sprouting was observed in $D$. composita. Extreme variation in sprouting was observed in the segments of the $D$. composita selection: At the end of 20 weeks, 93 percent of the segments from one rootstock of $D$. composita (P.I. 201783) had sprouted, while only 2 percent of those from another rootstock of this same selection had sprouted.

Preston and Haun (6) found many clones of D. spiculiflora to differ greatly with respect to sprouting. Campbell et al. (1) have also reported variation in rate and degree of sprouting in the White Lisbon yam, D. alata L. The variation in sprouting encountered in the various Dioscorea selections appears to be inherent to the Dioscorea plant.

VARIATION IN BUD DEVELOPMENT IN SEGMENTS FROM DIFFERENT AREAS OF THE ROOTSTOCK

It was observed in the present experiments that Dioscorea segments from intermediate areas of the rootstock sprout sooner than segments from the tips. Crown segments sprout even sooner than the intermediate segments. This variation in sprouting could have been caused by a variation in degree of dormancy in different areas of the rootstock. It would be expected, therefore, that, if a chemical were used to break dormancy, relatively high dosages would be needed to accelerate bud development in segments from areas with a high degree of dormancy (tips). Segments that sprout readily would probably respond to low dosages of the chemical.

Comparison of sprouting in segments from the intermediate and tip areas proved that there is a high degree of dormancy in the tips of the rootstock (table 1). Three months after the segments were planted, only 25 percent of the untreated tip segments had sprouted, while almost all of the untreated intermediate ones had sprouted. In the tip segments, with high dormancy, bud development was accelerated by increased dosage of ethylene chlorohydrin. In intermediate segments, the lowest dosage was effective. Additional propagation tests with Dioscorea P.I. 201783 confirmed these results. 


\section{BUD DEVELOPMENT IN ROOTSTOCK SEGMENTS FROM ACTIVELY GROWING AND DORMANT PLANTS}

Mature Dioscorea plants become dormant during the late autumn and winter months. The plants resume growth in the spring. Experiments carried out with rootstocks from actively growing and dormant plants showed that sprouting in segments from plants in active growth was

TABLE 1.-Sprouting from tip and intermediale D. composita (P.I. 201783) segments treated with ethylene chlorohydrin

\begin{tabular}{c|c|c|c|c|c|c}
\hline & \multicolumn{6}{|c|}{ Percentage sprouting1 at indicated weeks after planting } \\
\cline { 2 - 6 } $\begin{array}{c}\text { Concentration (ml. per } \\
\text { liter of container space) }\end{array}$ & \multicolumn{2}{|c|}{4} & \multicolumn{2}{|c|}{8} & \multicolumn{2}{|c}{12} \\
\cline { 2 - 7 } & Tip & Intermediate & Tip & Intermediate & Tip & Intermediate \\
\hline Controls & 0 & 0 & 0 & 63 & 25 & 96 \\
0.06 & 0 & 0 & 7 & 92 & 50 & 100 \\
.12 & 0 & 11 & 17 & 89 & 83 & 100 \\
\hline
\end{tabular}

1 Percentages based on averages of 13 tip and 27 intermediate segments.

TABLE 2.-Sprouting in segments from actively growing and dormant $\mathbf{D}$. composita (P.I. 201788) plants in segments trealed with ethylene chlorohydrin

\begin{tabular}{c|c|c|c|c}
\hline & \multicolumn{4}{|c}{ Percentage sprouting1 at indicated weeks after planting } \\
\cline { 2 - 5 } \begin{tabular}{c|c|c|c|c} 
Concentration (ml. per \\
liter of container space)
\end{tabular} & 4 & 8 & 4 & 8 \\
\cline { 2 - 5 } & \multicolumn{3}{|c|}{ Active } & \multicolumn{3}{|c|}{ Dormant } \\
\hline Controls & 29 & 71 & 3 & 28 \\
0.06 & 45 & 85 & 9 & 43 \\
.12 & 45 & 84 & 12 & 54 \\
\hline
\end{tabular}

1 Percentages based on average of 150 segments each for controls and ethylene chlorohydrin treatments.

accelerated by about 1 month (Table 2). There was 153 percent more sprouting from untreated segments planted in July than from similar segments planted in December. In segments treated with 0.06 and $0.12 \mathrm{ml}$. of ethylene chlorohydrin, this difference in sprouting was reduced to 98 and 55 percent, respectively. The segments planted in July had a high rate and degree of sprouting, irrespective of treatment. Further, no statistically significant differences were found between the untreated and the ethylene chlorohydrin-treated segments. This response also indicates a relatively low degree of dormancy in rootstocks from plants in active growth. 
STIMULATION OF BUD DEVELOPMENT WITH HIGH TEMPERATURE

It is of general knowledge that dormancy in plants can be broken with temperature treatments. To determine the effect of temperature on the sprouting of segments of a slow-to-sprout selection (D. composita P.I. 201783) and of a selection (D. floribunda P.I. 200119) that sprouts in a relatively short time, rootstock segments of these two selections were subjected to various temperature treatments.

Bud development in the $D$. floribunda selection (P.I. 200119) was significantly stimulated by the $31^{\circ} \mathrm{C}$. treatment (Table 3 ). However, the $35^{\circ} \mathrm{C}$. treatment retarded bud development. At $43^{\circ} \mathrm{C}$., all segments had rotted by the time they were first examined, which was 2 weeks after planting. At this time, all segments of the $D$. composita selection had rotted at all tem-

TABLE 3.-Sprouting in D. foribunda segments subjected to different temperatures

\begin{tabular}{c|c|c|c}
\hline \multirow{2}{*}{ Temperature ${ }^{\circ} \mathrm{C}}$. & \multicolumn{2}{|c}{ Percentage sprouting at indicated weeks after planting- } \\
\cline { 2 - 4 } & 2 & 5 & 9 \\
\hline $26-28$ & 0 & 30 & 50 \\
31 & 0 & 95 & 100 \\
35 & 0 & 20 & 32 \\
43 & 1 & 1 & 1 \\
\hline
\end{tabular}

Blank spaces stand for rotled.

peratures above 26 to $28^{\circ} \mathrm{C}$. Therefore, there were no data to present on this selection (P.I. 201783).

The high stimulative effect of the $31^{\circ} \mathrm{C}$. treatment on the $D$. floribunda selection agrees with the optimum temperature for bud-sprouting in $D$. spiculiflora found by Preston and Haun (6). Data presented here also confirm Dore's assertion (5) that new bud formation is stimulated most within a limited range of temperature.

\section{EFFECT OF ETHYLENE CHLOROHYDRIN TREATMENT ON BUD DEVELOPMENT IN ROOTSTOCK SEGMENTS}

Experiments with ethylene chlorohydrin were undertaken to find a method of chemical treatment that would accelerate the sprouting of segments. Preliminary trials carried out in the greenhouse to determine the amounts of the chemical to use, and the method of application, indicated that a concentration as low as $0.06 \mathrm{ml}$. of the chemical per liter of container space stimulated sprouting. Concentrations above $0.5 \mathrm{ml}$. injured the tissues.

The effectiveness of ethylene chlorohydrin in accelerating bud develop- 
ment in D. composita P.I. 201783 selection was tested in both field and greenhouse plantings.

In each of the three monthly examinations, the ethylene chlorohydrin treatments showed highly significant $(P$ less than 0.01 ) stimulation of bud development from the control (Table 4). However, although higher sprouting was obtained with $0.12 \mathrm{ml}$. than with $0.06 \mathrm{ml}$. of the chemical, differences between the two treatments at 12 weeks were not significant. During the first 2 months after planting, no significant difference in degree of sprouting was found between the segments planted in the greenhouse and those planted in the field. However, by the third month, sprouting in the field lagged behind that in the greenhouse. Polarity was exhibited by both treated and untreated segments, with buds formed at or near the apical end of the segments and roots at the basal end.

TABLE 4.-Sprouting in D. composita (P.I. 201788), segments treated with ethylene chlorohydrin

\begin{tabular}{c|c|c|c|c|c|c}
\hline & \multicolumn{5}{|c|}{ Percentage sprouting' at indicated weeks after planting- } \\
\cline { 2 - 7 } $\begin{array}{c}\text { Concentration (ml. per } \\
\text { Jiter of container space) }\end{array}$ & \multicolumn{2}{|c|}{4} & \multicolumn{2}{|c|}{8} & \multicolumn{2}{|c}{12} \\
\cline { 2 - 7 } & Greenhouse & Ficld & Greenhouse & Ficld & Grcenhouse & Field \\
\hline Controls & 3 & 1 & 28 & 25 & 45 & 27 \\
0.06 & 9 & 25 & 43 & 55 & 65 & 60 \\
.12 & 12 & 11 & 54 & 65 & 75 & 67 \\
\hline
\end{tabular}

${ }^{1}$ Percentages based on average of 150 segments for control and ethylene chlorohydrin treatments.

Denny and Miller (3) demonstrated that the rest period in the potato tuber can be broken with vapors of ethylene chlorohydrin. Denny and Stanton (4) showed that the rest period in woody plants also can be broken with ethylene chlorohydrin treatments. Dormant buds are involved in both instances. However, Warmke and Warmke (y) were able to differentiate shoot primordia on chicory and dandelion root segments with ethylene chlorohydrin solutions. In the experiments described here, the dormancy in rootstocks was broken by ethylene chlorohydrin, as evidenced by the initiation of new buds. These results using rootstocks of Dioscorea are similar to those of Warmke and Warmke in that the treatment induced initiation of new bud primordia.

\section{SUMMARY}

Selections of $D$. composita and $D$. floribunda can be propagated vegetatively from segments of the tuberous rootstock. Dormancy of the rootstock 
delays bud development and results in uneven sprouting and high loss from rot of the planted segments. The degree of dormancy in the rootstock appears to be affected by the genetic makeup of the plant, by a dormancy gradient that increases from crown to tip of the rootstock, and by the state of growth of the plant from which the rootstocks are taken. A $31^{\circ} \mathrm{C}$. temperature significantly stimulated bud development in the $D$. floribunda selections. Treatment of both $D$. composita and $D$. floribunda sections with dosages of 0.06 and $0.12 \mathrm{ml}$. of ethylene chlorohydrin showed highly significant stimulation of bud development.

Relatively even sprouting and accelerated bud development were obtained experimentally by using rootstocks from plants in active growth, by using segments from intermediate areas and by breaking the dormancy of the rootstocks.

\section{RESUMEN}

Las selecciones de las especies Dioscorea composita y $D$. floribunda pueden propagarse vegetativamente por medio de pedazos del rizoma tuberoso. El estado de reposo del rizoma tuberoso retarda la formación y el desarrollo de las yemas en los pedazos, de manera que la germinación no es uniforme y se pierde un gran número de los pedazos que tardan en germinar debido a la podredumbre. Tal parece que el grado de reposo del rizoma tuberoso es afectado por la constitución genética de la planta y por el estado de crecimiento en que se encuentre la planta madre, ya sea en pleno crecimiento o en reposo. El grado de reposo aumenta de la corona hacia el ápice del rizoma.

La germinación de los pedazos de rizoma de las selecciones de $D$. floribunda a una temperature de $31^{\circ} \mathrm{C}$., estimuló la formación y el desarrollo de yemas adventicias. El tratamiento de los pedazos de rizoma de las especies $D$. composita y $D$. floribunda con dosis de 0.06 a $0.12 \mathrm{ml}$. de chlorhidrina de etileno, por litro de espacio en el envase, estimuló significativamente la formación de yemas adventicias.

Relativamente, tanto la germinación como el desarrollo acelerado de las yemas adventicias pudieron lograrse experimentalmente mediante el uso de rizomas de plantas en crecimiento activo, de los cuales se utilizaron segmentos de sus áreas intermedias y también mediante la suspensión del período de reposo de los rizomas.

\section{LITERATURE CITED}

1. Campbell, J. S., Chukwueke, F. A., Teriba, F. A., and Ho-A-Shu, H. V. S., Some physiological investigations into the White Lisbon yam (Dioscorea alata L.), Emp. J. Expt. Agr. 30: 108-14, 1962.

2. Correll, D. S., Schubert, B. G., Gentry, H. S., and Hawley, W. O., The search for plant precursors of cortisone, Econ. Bot. 9: 307-76, 1955. 
3. Denny, F. E., and Miller, L. P., Further experiments on shortening the rest period of potato tubers, Contrib. Boyce Thomp. Inst. \%: 157-81, 1935.

4. Denny, F. E., and Stanton, N. E., Chemical treatments for shortening the rest period of pot-grown woody plants, Amer. J. Bot. 15: 327-36, 1928.

5. Dore, J., Physiology of regeneration in cormophytes, Encyclopedia of Plant Physiology XV, Springer-Verlag, Berlin, Germany, pp. 1-91, 1965.

6. Preston, W. H., Jr., and Haun, J. R., Relationship of temperature and photoperiod to growth, flowering, senescence, and dormancy of Dioscorea spiculiflora, Bot. Gaz. 124: 346-53, 1963.

7. Warmke, H. E., and Warmke, G. L., The role of auxin in the differentiation of root and shoot primordia from cuttings of Taraxacum and Chicorium, Amer. J. Bot. s7: 272-80, 1950. 